\title{
KEWENANGAN PENJABAT KEPALA DESADALAM MENGANGKAT PERANGKAT DESA
}

\author{
Abdul Rohman, S.H., S.Pd.I., M.H. \\ Fakultas Hukum Universitas Islam Bandung \\ abe131185@gmail.com \\ DOI : https://doi.org/ 10.29313/shjih.v18i1.6026
}

\begin{abstract}
ABSTRAK
Pemerintahan Desa dipimpin oleh seorang Kepala Desa, pada kondisi Kepala Desa tidak dapat melaksanakan tugasnya, maka pemerintahan tersebut dipimpin oleh Penjabat Kepala Desa. Dalam Pemerintahan Desa, Penjabat Kepala Desa dibantu oleh Perangkat Desa. Pertanyaannya apakah Penjabat Kepala Desa dapat melakukan pengangkatan Perangkat Desa? Untuk menjawab pertanyaan teraebut, penulis melakukan penelitian hukum normatif, dengan melakukan kajian bahan Pustaka, dengan pendekatan mengkaji dan menelaah peraturan perundangundangan terhadap pokok masalah yang diteliti. Jawaban dari pembahasan penelitian ini adalah Penjabat Kepala Desa memiliki kewenangan yang sama dengan Kepala Desa secara definitif Berdasarkan Pasal 4A Ayat (2) Peraturan Menteri Dalam Negeri Nomor 83 Tahun 2015 tentang Pengangkatan dan Pemberhentian Perangkat Desa.
\end{abstract}

Kata Kunci: Kewenangan, Penjabat Kepala Desa, Perangkat Desa.

\begin{abstract}
The Village Government is led by a Village Head, on the condition that the Village Head is unable to carry out his duties, the government is led by the Acting Village Head. In the Village Government, Acting Village Heads are assisted by Village Officials. The question is whether the Acting Village Head can appoint the Village Apparatus? To answer these questions, the author conducts normative legal research, by studying literature material, with an approach to reviewing and reviewing the laws and regulations on the subject matter being investigated. The answer of this research discussion is that the Acting Village Head has the same authority as the Village Head definitively. Based on Article 4A Paragraph (2) Regulation of the Minister of Home Affairs No. 83 of 2015 concerning Appointment and Dismissal of Village Officials.
\end{abstract}

Keywords: Authority, Acting Village Head, Village Official. 


\section{A. PENDAHULUAN}

Indonesia adalah negara hukum, hal ini diatur pada Pasal 1 Ayat (3) Undang-Undang Negara Republik Indonesia Tahun 1945, selanjutnya penulis sebut UUD $1945^{1}$. Yang disebut dengan negara hukum ialah negara yang berdiri diatas hukum yang menjamin keadilan kepada warga negaranya. ${ }^{2}$ Hukum bertujuan mengatur tata tertib masyarakat. ${ }^{3}$ Melihat tujuan dari hukum tersebut, maka segala tata kehidupan bernbegara penting memperhatikan hukum, baik masyarakat maupun pemerintah.

Indonesia sebagai Negara kesatuan dalam penyelenggaraan pemerintahannya dikenal ada pemerintah pusat dan pemerintah daerah. Pemerintah Daerah yang merupakan sub sistem penyelenggaraan pemerintah nasional memiliki kewenangan untuk mengatur dan mengurus rumah tangganya sediri. 4 Penyelenggaraan pemerintahan daerah diatur dalam Pasal 18 Ayat (7) UUD 1945, yaitu susunan dan tata cara penyelenggaraan pemerintahan daerah diatur dalam undang-undang. selanjutnya berdasarkan ketentuan tersebubut,pengaturan mengenai pemerintahan daerah lebih spesifik terdapat pada Undang-Undang Nomor 23 Tahun 2014 yang kemudian telah terjadi perubahan dengan UndangUndang Nomor 9 Tahun 2015 Tentang Pemerintahan Daerah, selanjutnya penulis sebut UU Pemda.

Topik penelitian penulis yaitu Pemerintahan Desa, pada Pasal 20 Ayat (3) dinyatakan urusan konkuren yang menjadi kewenangan daerah Kabupaten/Kota diselenggarakan sendiri oleh daerah Kabupaten/Kota atau dapat ditugaskan

\footnotetext{
${ }^{1}$ Lihat Pasal 1 Ayat (3) Undang-Undang Dasar Tahun 1945

${ }^{2}$ Moh. Kusnadi dan Harmaili Ibrahim, Pengantar Hukum Tata Negara,PD. Budi Chaniago, Jakarta Selatan, 1988, Hal. 153.

${ }^{3}$ Pipin Syaripin, Pengantar Ilmu Hukum, CV. Pustaka Setia, Bandung, 1999. Hal. 20.

${ }^{4}$ Efik Yusdiansyah, "Peran Badan Legislasi Daerah Dalam Mmenjalankan Fungsi Legislasi di DPRD Provinsi Jawa Barat", SYIAR HUKUM, VoL. XIV No. 2, September 2012 - Januari 2013, Hal. 189.
} 
sebagian pelaksanaannya kepada Desa. Dalam pelaksanaan pemerintahan desa, dikenal kepala desa sebagai pimpinan dari pemerintahan tersebut. Kepala desa ini memimpin wilayah terkecil struktur organisasi pemerintahan masyarakat di Indonesia. Pasal 1 Undang-Undang Nomor 6 Tahun 2014 Tentang Desa, selanjutnya penulis sebut UU Desa didefinisikan bahwa: "Desa adalah desa dan desa adat atau yang disebut dengan nama lain, selanjutnya disebut Desa, adalah kesatuan masyarakat hukum yang memiliki batas wilayah yang berwenang untuk mengatur dan mengurus urusan pemerintahan, kepentingan masyarakat setempat berdasarkan prakarsa masyarakat, hak asal usul, dan/atau hak tradisional yang diakui dan dihormati dalam sistem pemerintahan Negara Kesatuan Republik Indonesia". Selanjutnya Pasal 2 UU Desa menjelaskan: "Pemerintah Desa adalah Kepala Desa atau yang disebut dengan nama lain dibantu perangkat Desa sebagai unsur penyelenggara Pemerintahan Desa". ${ }^{5}$ Melihat bunyi pasal tersebut, dapat dipahami bahwa penyelenggaraan pemerintahan desa memiliki kewenangan berdasarkan khasanah keistimewaan daerah yang dimilikinya, selain itu, Desa memiliki pimpinan yaitu Kepala Desa yang dibantu perangkat desa untuk mempasilitasi pelayanan bagi masyarakatnya. Perangkat desa terdiri atas Skretaris Desa, Pelaksana Kewilayahan, dan Pelaksana Teknis. ${ }^{6}$

Semangat utama dari lahirnya undang-undang desa tersebut adalah bagaimana memperkuat desa, baik secara kelembagaannya maupun sistem pemerintahannya dalam rangka mensejahterakan masyarakat, karena desa dengan segenap atribut pemerintahannya adalah arena yang berhadapan langsung dengan

\footnotetext{
${ }^{5}$ Pasal 1 dan 2 Undang Nomor 6 Tahun 2014 Tentang Desa

${ }^{6}$ Ren Yani, Dkk., "Degradasi Integritas Publik Politisi Dalam Penggunaan Anggaran Dana Desa Bukit Pamewa Kecamatan Sipora Utara Kabupaten Kepulauan Mentawai”, JISPO, Vol. 8 No. 2 , Juli-Desember 2018.
} 
rakyat. Pemerintahan desa adalah sentra kekuasaan politik lokal yang dipersonifikasi lewat Kepala Desa dan perangkatnya. ${ }^{7}$

Dalampelaksanaannya, Pemerintahan desa dimungkinkan Kepala Desa tidak melaksanakan tugasnya sesuai dengan batas masa kerja, hal ini dikarenakan beberapa faktor seperti yang dijelaskan pada Pasal 54 Ayat (1) Peraturan Pemerintah Nomor 43 Tahun 2014 sebagaimana telah dirubah oleh Peraturan Pemerintah Nomor 47 Tahun 2015 Tentang Desa, selanjutnya penulis sebut PP Desa, Kepala Desa berhenti karena: “(a) meninggal dunia, (b) permintaan sendiri, atau (c) diberhentikan". Yang dimaksud dengan poin (a) pada PP Desa tersebut cukup jelas, yaitu kepala desa tidak dapat melanjutkan kepemimpinannya karena meninggal dunia. Selanjutnya, poin (b) menjelaskan bahwa Kepala Desa atas permintaannya sendiri beralih profesi ataupun kegiatan lainnya, dan mengajukan permintaan untuk mundur dari kepemimpinannya sebagai Kepala Desa. Untuk poin (c), kepala desa diberhentikan karena sakit yang berkepanjangan dan tidak dapat melakukan kegiatan kepemimpinan, ataupun melakukan tindakan yang bertentangan dengan hukum.

Pentingnya penyelenggaraan pemerintahan yang mencerminkan pelayanan publik, maka perlu penyelenggaraan pemerintahan desa dengan kelengkapan perangkat desa, hal ini diharapkan terciptanya pemerintahan yang baik. Asas umum pemerintahan yang baik adalah asas yang menjunjung tinggi norma kesusilaan, kepatutan, dan norma hukum untuk mewujudkan penyelenggaraan negara yang bersih dan bebas dari korupsi, kolusi, dan nepotisme. ${ }^{8}$ Untuk mencapai asas tersebut penting adanya ketentuan yang secara legal mengatur kedudukan

\footnotetext{
${ }^{7}$ Simson Tondo, "Perebutan Desa: Tinjauan Pemilihan Kepala Desa Serentak di Kabupaten Halmehera Utara Tahun 2018”, Gema Publica Jurnal Manajemen dan Kebijakan Publik, Vol. 4 No. 1, Maret 2019.

${ }^{8}$ Pipin Syarifin dan Dedah Jubaedah, Hukum Pemerintahan Daerah, Pustaka Bani Quraisy, Bandung, 2005, Hal.80.
} 
pemimpin dalam suatu pemerintahan, dan pemerintahan desa dipimpin oleh seorang Kepala Desa.

Kekosongan kekuasaan jabatan Kepala Desa dikarenakan permintaan sendiri pernah terjadi di Pemerintahan Desa dekat tempat tinggal penulis, yaitu Desa Haurngombong Kecamatan Pamulihan Kabupaten Sumedang pada tahun 2019, Bapak Cecep Saepudin selaku Kepala Desa masih menyisakan masa jabatan 1 tahun dan memilih mundur. Pengunduran diri pegawai dapat terjadi karena berbagai alasan yang dapat bersumber dari pegawai itu sendiri seperti kepuasan kerja yang rendah, alasan keluarga, dan lain-lainnya dimana itu menjadi hak pegawai. ${ }^{9}$ Pengunduran diri Bapak Cecep Saepudin dari jabatan Kepala Desa dikarenakan mengikuti kompetisi pemilihan calon Dewan Perwakilan Daerah Kabupaten Sumedang.

Kekosongan kekuasaan jabatan Kepala Desa ini juga terjadi di Desa Mekar Bakti dimana letak desa tersebut tidak jauh daerahnya dengan Desa Haurngombong, Kepala Desa terpilih Bapak Juansa mendadak sakit struk setelah pemilihan Kepala Desa dilangsungkan, kemudian Pemerintahan Desa diambil alih oleh sekretaris desa sebagai Penjabat Kepala Desa. Apabila dalam kondisi desa memerlukan personil Perangkat Desa dikarenakan kondisi tertentu, misalnya perangkat Desa meninggal dunia, atau kondisi yang lainnya, apakah Penjabat Kepala Desa mempunyai kewenangan dalam mengangkat perangkat Desa?

\section{B. METODE}

Dalam penelitian ini, penulis menggunakan metode penelitian hukum normatif. Metode atau cara yang digunakan di dalam penelitian hukum yang dilakukan dengan cara meneliti bahan pustaka yang ada, literature-literatur dan peraturan perundang-undangan yang ada kaitannya dengan permasalahan yang

\footnotetext{
${ }^{9}$ Marihot Tua Efendi Hariandia, Manajemen Sumber Daya Manusia Pengadaan, Pengembangan, Pengkompensasian, dan Peningkatan Produktifitas Pegawai, Grasindo, Jakarta, 2002, Hal. 162.
} 
diteliti. ${ }^{10}$ Untuk pendekatan yang digunakan, penulis menggunakan pendekatan perundang-undangan mauppun konseptual. Pendekatan perundang-undangan (Staute Aprproach) yaitu pendekatan dengan cara mengkaji dan menelaah peratuan perundang-undangan yang berkaitan dengan pokok persoalan. ${ }^{11}$ Pendekatan konseptual dimaksudkan untuk menambah pandangan penulis mengenai bagaimana yang terjadi di lapangan dan untuk menambah isu hukum pembahasan permasalahan ini. Wawasan mengenai teori keilmuan hukum menjadi tambahan terhadap solusi dalam menyelesaikan permasalahan yang sedang dibahas. Sehingga hasil yang didapat menjadi sumbangsi pemikiran terhadap penerapannya dilapangan, khususnya yang berhubungan dengan topik pada penelitian ini.

\section{PEMBAHASAN}

Penyelenggaraan Pemerintahan Desa tidak terpisahkan dari penyelenggaraan otonomi daerah. Pemerintahan Desa merupakan unit terdepan (ujung tombak) dalam pelayanan kepada masyarakat serta tombak strategis untuk keberhasilan otonomi daerah. ${ }^{12}$ Pemerintahan Desa yang secara struktual tetap berada di bawah Kabupaten/Kota menjadi bagian pemerintahan daerah Kabupaten/Kota, namun pengelolaan terhadap Desa dilakukan secara mandiri,

\footnotetext{
${ }^{10}$ S. Soekano dan S. Mamuji, Penelitian Hukum Normatif Suatu TinjauanSingkat. cetakan ke-2, PT. Raja Graf. Persada, Jakarta, 2009.

${ }^{11}$ Nanang Zulkarnaen, "Kewenangan Kepala Desa Dalam Mengangkat dan Memberhentikan Perangkat Desa Ditinjau Dari Undang-Undang Nomor 6 Tahun Tentang Desa”,Civicus PKIP UMMat, Vol. 6 No. 1 Maret, 2018. Hal. 27.

${ }^{12}$ Nuraini dan Irwan Nasution, "Kinerja Aparat Desa Dalam Penyelenggaraan Pemerintahan Desa Pantai Labu Pekan”, Jurnal Ilmu Pemerinahan dan Sosial Politik 2 (2) (2014), Hal. 100.
} 
pemerintah daerah hanya sebagai pengawas dan pembina dalam mencapai tujuan pembangunan daerah melalui pemberdayaan Desa. ${ }^{13}$

Desa merupakan otonomi murni yang ada secara turun temurun yang berlandaskan kepada demokrasi masyarakat. Unsur demokrasi yang digambarkan dengan sistem pemilihan pemimpin di lingkungan desa tersebut baik kepala desa maupun kepala dusun, sedangkan perangkat-perangkat lain ditetapkan oleh kepala desa atas dasar musyawarah. Penyelenggaran Pemerintahan desa yang diharapkan mampu menciptakan pelayanan publik, maka penting memperhatikan kejasama yang baik antara pemimpin dengan perangkatnya. Pemerintahan publik adalah pelayanan yang diberikan oleh pemerintah sebagai penyelenggara negaraterhadap masyarakatnya guna memenuhi kebutuhan dari masyarakat itu sendiri dan memiliki tujuan untuk meningkatkan kesejahteraan masyarakat. ${ }^{14}$ Penyelenggaraan pemerintahan dilakukan oleh pemerintah desa yang terdiri dari kepala desa yang dibantu oleh perangkat desa, sedangkan penetapan kebijaksanaan pemerintahan, pembangunan dan pembinaan masyarakat dilakukan bersama antara pemerintah desa dengan wakil masyarakat. ${ }^{15}$

Pemerintahan yang mencerminkan pelayanan publik, merupakan bentuk dari tanggung jawab pemerintah desa dengan perangkat desa secara bertanggung jawab kepada masyarakat. Bertanggung jawab kepada masyarakat artinya kesediaan memberikan pelayanan sebaik mungkin sesuai dengan profesinya, tanpa

\footnotetext{
${ }^{13}$ Agus Adhari, “Analisis Hukum Pembentukan Badan Usaha Milik Desa Dalam Upaya Meningkatkan Pendapatan Asli Desa di Kecamatan Babalan Kabupaten Langkat”, Dialogia Lulidca: Jurnal Hukum Bisnis dan Inverstasi, Vol. 9 No. 1, November 2017, Hal. 14.

${ }^{14}$ Juniarso Ridwan dan Achmad Sodik Sudrajat, Hukum Administrasi Negara dan Kebijakan Pelayanan Publik, Nuansa, Bandung, 2012, Hal. 19.

${ }^{15}$ Arief Sumeru, "Kedudukan Kepala Desa Dalam Penyelenggaraan Pemerintahan Desa”, JKMP, Vol. 4, No. 1, Maret 2016.
} 
membedakan antara pelayanan bayaran dan pelayanan cuma-cuma serta menghasilkan pelayanan yang bermutu, yang berdampak positif bagi masyarakat. ${ }^{16}$

Pada Pasal 25 UU Desa, disebutkan:"Pemerintah Desa sebagai mana dimaksud dalam Pasal 23 adalah Kepala Desa atau yang disebut dengan nama lain dan yang dibantu oleh perangkat Desa atau yang disebut dengan nama lain". ${ }^{7}$ Maksud dari ketentuan tersebut adalah penamaan untuk kepala desa maupun nama lain pada daerah tertentu yang memiliki karakteristik berbeda. Contohnya sebutan “Kuwu” (Cirebon, Berebes, Tegal), "Wali Nagari”(Sumatra Barat), "Pambakal" (Kalimantan Selatan), "Hukum Tua" (Sulawesi Utara), dan "Perbekel” (Bali).

Berbagai hal mengenai berhentinya Kepala Desa Definitif karena berbagai hal baik kepentingan prbadinya maupun karena secara undang-undang tidak layak lagi memimpin Pemerintahan Desa, maka kekosongan kekuasaan tersebut harus segera terisi. Selanjutnya, undang undang tentang Desa tahun 2014 meyebutkan bahwa pengganti pejabat Kepala Desa adalah pejabat sementara yang merupakan seorang pegawai negeri sipil di kalangan pemerintah daerah. ${ }^{18}$ Sselanjutnya untuk melaksanakan UU Desa mengenai pengisian kekosongan kekuasaan kepemimpinan Pemerintahan Desa tersebut, ketentuan itu dimuat pada Pasal 57 Ayat (3) PP Desa, yaitu:"Bupati/Wali Kota mengangkat Penjabat Kepala Desa sebagaimana dimaksud pada ayat (1) dari pegawai negeri sipil dari Pemerintah Kabupaten/Kota". ${ }^{19}$ Melihat bunyi pasal tersebut maka peran Bupati/Wali kota untuk pengisian kekosongan Kepala Desa di suatu daerah sangat sentral, dengan demikian, maka Bupati/Wali Kota penting untuk melakukan penunjukan serta pengangkatan agar pemerintahan desa dapat berjalan secara optimal, yaitu dengan

\footnotetext{
${ }^{16}$ Abdulkadir Muhammad, Etika Profesi Hukum, PT. Citra Aditya Sakti, Bandung, 2006, Hal.60.

${ }^{17}$ Lihat Pasal 25 Undang-Undang Nomor 6 Tahun 2014 Tentang Desa

18 Vela Graeta Widyasari,'Diskresi Kepala Daerah Dalam Penetapan Penjabat Kepala Desa”, Lentera Hukum, Vol. 3 No. 2, Juli 2016.

${ }^{19}$ Lihat Pasal 57 Ayat (3) Peraturan Pemerintah Nomor 47 Tahun 2015 Tentang Desa
} 
menempatkan Pegawai Negeri Sipil (PNS) untuk menjadi Penjabat Kepala Desa pada daerah yang terdapat kekosongan jabatan Kepala Desa tersebut.

\section{Kewenangan Penjabat Kepala Desa Mengangkat Perangkat Desa}

Pada bagian ini, penulis membahas mengenai kewenangan dari Penjabat Kepala Desa dalam pengangkatan Perangkat desa. Setelah menjelaskan mengenai Penjabat Kepala Desa, maka penting diketahui definisi dari perangkat Desa.

Prosesperekrutanperangkatdesadinilaipentingdalamupayamenunjang jalannya pemerintahan desa yang efektif, maka Kepala Desa perlu mengangkat perangkat desa yang berorientasi pada kinerja. Secara konsep, kinerja menurut Simanjuntak(2005:1)merupakantingkatanpencapaianhasilataspelaksanaantugastugastertentu.Dengandemikian,kinerjayanglebihintensifsertaoptimaldiperlukan demi optimalisasi bidang tugas yang dibebankan kepadanya. ${ }^{20}$

Pasal 1 Ayat (5) Peraturan Menteri Dalam Negeri Nomor 66 Tahun 2017 perubahan atas Peraturan Menteri Dalam Negeri Nomor 82 Tahun Tahun 2015 Tentang Pengangkatan dan Pemberhentian Kepala Desa selantnya penulis sebut Permendagri Desa, disebutkan bahwa: "Perangkat Desa adalah unsur staff yang membantu Kepala Desa dalam penyusunan kebijakan dan koordinasi yang diwadahi dalam Sekretariat Desa, dan unsur pendukung tugas Kepala Desa dalam pelaksanaan kebijakan yang diwadahi pelaksana teknis dan unsur pelaksanaan".Melihat bunyi pasal tersebut dapat dikatakan bahwa sangat urgen pelayanan perangkat desa guna mendukung kinerja Kepala Desa, seingga pembentukan struktur pemerintahan desa perlu dilakukan sebagai langkah menuju pelayanan yang optimal terhadap masyarakat.

Pengaturan yang tertuang pada UU Desa, hanya ada penjelasan kewenangan Kepala Desa mengangkat dan memberhentikan perangkat Desa, belum ditemukan kewenangan Penjabat Kepala Desaterhadap terhadap pengangkatan perangkat desa. Dalam pengangkatan perangkat Desa oleh kepala Desa bukanlah menjadi

\footnotetext{
${ }^{20}$ Baharudin Muhammad Faturahman, "Aktualisasi Demokrasi dalam Perekrutan dan Penjarungan Perangkat Desa, Jurnal Sospol Vol. 4 No. 1, Januari-Juni 2018.
} 
kewenangan yang melekat secara mutlak terhadap kepala Desa dengan kehendak sendiri tanpa harus mempertimbangkan syarat-syarat sebagai perngkat Desa dan mekanisme pengangkatan perangkat Desa, peroses penjaringan dan penyaringan yang dilakukan tentu dengan tujuan agar mendapatkan hasil yang baik yaitu perangkat Desa yang diangkat memiliki etos kerja yang baik dan perofesional. ${ }^{21}$ Pemerintah desa merupakan entitas birokrasi pemerintahan terkecil yang memiliki peran krusial dalam penyediaan pelayanan publik. Dalam mendukung terlaksananya pembangunan dan juga pelayanan publik di tingkat desa, tentunya pemerintah desa memerlukan sumber daya manusia yang memiliki kecakapan dan keterampilan tertentu. ${ }^{22}$ Syarat seseorang menjadi perangkat desa diatur pada Pasal 50 Ayat (1) UU Desa, yaitu: "Perangkat Desa sebagaimana dimaksud dalam Pasal 48 diangkat dari warga Desa yang memenuhi persyaratan: (a) Berpendidikan paling rendah sekolah menengah umum atau yang sederajat; (b) Berusia 20 (dua puluh) tahun sampai dengan 42 (empat puluh dua) tahun; (c) Terdaftar sebagai penduduk Desa dan bertempat tinggal di Desa paling kurang 1 (satu) tahun sebelum pendaftaran; dan (d) Syarat lain yang ditentukan dalam Peraturan Daerah Kabupaten/Kota". ${ }^{23}$ Memperhatikan pengaturan tentang syarat perangkat desa, pada dasarnya kinerja perangkat desa ini harus profesional, sehingga pelayanan publik berkualitas. Maka tidak sembarangan orang dapat direkrut untuk mengisi kekosongan perangkat desa, sehingga penting memperhatikan persyaratan yang telah ditentukan pada UU Desa tersebut dari mulai tingkat pendidikan, usia, identitas kependudukan, serta yang lainnya.

\footnotetext{
${ }^{21}$ Nanang Zulkarnaen, "Kewenangan Kepala Desa Dalam Mengangkat dan Memberhentikan Perangkat Desa Ditinjau Dari Undang-Undang Nomor 6 Tahun 2014 Tentang Desa”, Loc. Cit. Hal. 32.

${ }^{22}$ Muhammad Siwi Nugraha, "Tantangan Mewujudkan Meritokrasi Birokrasi Pemerintahan Desa”, Gema Publica Jurnal Manajemen dan Kebijakan Publik, Vol. 4 No. 2, Oktober 2019.

${ }^{23}$ Lihat Pasal 50 Ayat (1) UU Nomor 6 Tahun 2014 Tentang Desa
} 
Untuk mengulas apakah berwenang atau tidaknya Penjabat Kepala Desa mengangkat dan memberhentikan perangkat Desa, perlu kita menganalisis pada peraturanperundang-undangan sebagai pelaksana, yang berhubungan dengan Pemerintahan Desa.Indonesia yang merupakan negara hukum penting memberikan kepastian hukum dalam setiap tindakan hukum. Hukum tidak bekerja menurut ukuran dan pertimbangannya sendiri, melainkan dengan memikirkan dan mempertimbangkan apa yang baik untuk dilakukan bagi masyarakat. ${ }^{24}$

Sebagaimana yang telah dipaparkan pada latar belakang masalah, contoh kasus diangkatnya Penjabat Kepala Desa di Desa Haurngombong Kecamatan Pamulihan Kabupaten Sumedang adalah mundurnya Kepala Desa definitik dikarenakan mencalonkan diri menjadi calon anggota Dewan Perwakilan Daerah Kabupaten Sumedang. Sehubungan dengan hal tersebut, maka Pemerintahan Desa tersebut dijalankan oleh seorang Penjabat Kepala Desa. Adapun kewenangan Penjabat Kepala Desa berdasarkan Pasal 4A Permendagri Desa yaitu:

Ayat (1):

"Calon Kepala Desa terpilih yang meninggal dunia, berhalangan tetap atau mengundurkan diri dengan alasan yang dapat dibenarkan sebelum pelantikan, calon terpilih dinyatakan gugur dan bupati/wali kota mengangkat pegawai negeri sipil dari Pemerintah Daerah kabupaten/kota sebagai Penjabat Kepala Desa;

Ayat (2):

Penjabat Kepala Desa sebagaimana dimaksud pada ayat (1) melaksanakan tugas dan wewenang Kepala Desa sampai dengan dilantiknya Kepala Desa hasil pemilihan langsung secara serentak sesuai dengan ketentuan peraturan perundang-undangan", 25

\footnotetext{
${ }^{24}$ Sutjipto Rahardjo, Ilmu Hukum Cetakan Ke 6, PT. Citra Aditya Bakti, Semarang, 2006, Hal. 151.

${ }^{25}$ Lihat Pasal 4A Peraturan Menteri Dalam Negeri Nomor 66 Tahun 2017 Tentang Pengangkatan dan Pemberhentian Kepala Desa.
} 
Mellihat kutipan Pasal 4A diatas, maka penulis menganalisis pada ayat (2) bahwa Penjabat Kepala Desa dapat melaksanakan tugas dan wewenang yang melekat pada Kepala Desa secara definitif, sampai dengan adanya Kepala Desa baru berdasarkan hasil pemilihan langsung sesuai ketentuan perundang-undangan. Artinya kewenangan yang melekat pada kepala desa sepenuhnya dapat dilaksanakan oleh Penjabat Kepala Desa, salah satunya adalah ketentuan yang ada pada Pasal 26 Ayat (2) UU Desa, yaitu:Dalam melaksanakan tugas sebagaimana dimaksud pada ayat (1), Kepala Desa berwenang: ${ }^{26}$

a. Memimpin penyelenggaraan Pemerintahan Desa;

b. Mengangkat dan memberhentikan perangkat Desa;

c. Memegang kekuasaan pengelolaan Keuangan dan Aset Desa;

d. Menetapkan Peraturan Desa;

e. menetapkan Anggaran Pendapatan dan Belanja, Desa;

f. Membina kehidupan masyarakat Desa;

g. Membina ketenteraman dan ketertiban masyarakat Desa;

h. Membina dan meningkatkan perekonomian Desa serta mengintegrasikannya agar mencapai perekonomian skala produktif untuk sebesar-besarnya kemakmuran masyarakat Desa;

i. Mengembangkan sumber pendapatan Desa;

j. Mengusulkan dan menerima pelimpahan sebagian kekayaan negara guna meningkatkan kesejahteraan masyarakat Desa;

k. Mengembangkan kehidupan sosial budaya masyarakat Desa;

1. Memanfaatkan teknologi tepat guna;

m. Mengoordinasikan Pembangunan Desa secara partisipatif;

n. Mewakili Desa di dalam dan di luar pengadilan atau menunjuk kuasa hukum untuk mewakilinya sesuai dengan ketentuan peraturan perundang-undangan, dan;

o. Melaksanakan wewenang lain yang sesuai dengan ketentuan peraturan perundang-undangan".

${ }^{26}$ Lihat Pasal 26 Ayat (2) UU Nomor 6 Tahun 2014 Tentang Desa 
Melihat ketentuan di atas, maka sesuai Pasal 26 Ayat (2) Poin (b) UU Desa yaitu kewenangan Kepala Desa untuk mengangkat dan memberhentikan perangkat Desa, kemudian dihubungkan dengan Pasal 4A Ayat (2) yang memberikan kewenangan Penjabat Kepala Desa menjalankan tugas dan wewenang Kepala Desa, maka baik Kepala Desa maupun Penjabat Kepala Desa memiliki kewenangan yang sama, termasuk perekrutan dan pemberhentian Perangkat Desa berdasarkan peraturan perundang-undangan yang berlaku.

\section{Mekanisme Pengangkatan Perangkat Desa oleh Penjabat Kepala Desa.}

Sebagaimana poin pertama, telah didapatkan jawaban bahwa Penjabat Kepala Desa memiliki kewenangan seperti halnya Kepala Desa, maka pada bagian kedua ini penulis akan memaparkan memaparkan bagaimana mekanisme Penjabat Kepala Desa melakukan pengangkatan dan pemberhentian Perangkat Desa berdasarkan peraturan perundang-undangan yang berlaku.

Melihat Pasal 4A Ayat (2) Permendagri Desa, maka kewenangan Penjabat Kepala Desa sama dengan Kepala Desa, maka dipastikan pengangkatan Perangkat Desa oleh Penjabat Kepala Desa tidak berbeda prosedurnya oleh Kepala Desa. Berikut adalah tahapannya:

\section{a. Memenuhi persyaratan}

Persyaratan yang harus dipenuhi oleh calon perangkat desa diatur dalam Pasal 2 Peraturan Menteri Dalam Negeri Nomor 83 Tahun 2015 Tentang Pengangkatan dan Pemberhentian Perangkat Desa, selanjutnya penulis sebut Permendagri Perangkat Desa, yaitu:

(1) Perangkat Desa diangkat oleh Kepala Desa dari warga Desa yang telah memenuhi persyaratan umum dan khusus.

(2) Persyaratan umum sebagaimana dimaksud pada ayat (1) adalah sebagai berikut:

(a) Berpendidikan paling rendah sekolah menengah umum atau yang sederajat;

(b) Berusia 20 (dua puluh) tahun sampai dengan 42 (empat puluh dua) tahun; 
(c) Dihapus;

(d) Memenuhi kelengkapan persyaratan administrasi.

(3) Persyaratan khusus sebagaimana dimaksud pada ayat (1) yaitu persyaratan yang bersifat khusus dengan memperhatikan hak asal usul dan nilai sosial budaya masyarakat setempat dan syarat lainnya.

(4) Persyaratan khusus sebagaimana dimaksud pada ayat (3) ditetapkan dalam peraturan daerah. ${ }^{27}$

Berdasarkan paparan di atas, untuk mengikuti seleksi bakal calon perangkat desa harus memiliki Ijazah serendah-rendahnya Sekolah Menengah Umum (SMU), ataupun yang dengan tingkatan ketentuan tersebut. Selain pendidikan, bakal calon perangkat desa usianya tidak boleh kurang dari 20 tahun, serta melebihi 42 tahun. Hal ini ditujukan agar pengelola pemerintahan desa pada usia yang produktif, sehingga pelayanan terhadap masyarakat dapat dilakukan secara cepat dan tepat sasaran. Adapun persyaratan khusus pada perekrutan perangkat desa, bakal calon dapat diusulkan oleh berbagai pihak yang dianggap dituakan, apabila daerah tersebut memiliki kekhasan dalam adat istiadat maupun kepercayaan secara otonom, dan telah adanya penetapan berdasarkan Peraturan Daerah Kabupaten/Kota.

Selanjunya, memperhatikan pada pasal 3 Permendagri Perangkat Desa, terdapat penekanan persyaratan administrasi seperti yang ada pada Pasal 2 Ayat (1) Poin (d), meliputi:28

(1) Kartu Tanda Penduduk atau surat keterangan tanda penduduk;

\footnotetext{
${ }^{27}$ Pasal 2 Peraturan Menteri Dalam Negeri Nomor 83 Tahun 2015 Tentang Pengangkatan dan Pemberhentian Perangkat Desa

${ }^{28}$ Lihat Pasal 3 Peraturan Menteri Dalam Negeri Nomor 83 Tahun 2015 Tentang Pengangkatan dan Pemberhentian Perangkat Desa
} 
(2) Surat pernyataan bertakwa kepada Tuhan Yang Maha Esa yang dibuat oleh yang bersangkutan di atas kertas bermaterai;

(3) Surat pernyataan memegang teguh dan mengamalkan Pancasila, Undang-Undang Dasar Negara Republik Indonesia Tahun 1945, mempertahankan dan memelihara keutuhan Negara Kesatuan Republik Indonesia dan Bhinneka Tunggal Ika, yang dibuat oleh yang bersangkutan diatas kertas segel atau bermaterai cukup;

(4) Ijazah pendidikan dari tingkat dasar sampai dengan ijazah terakhir yang dilegalisasi oleh pejabat berwenang atau surat pernyataan dari pejabat yang berwenang;

(5) Akte kelahiran atau surat keterangan kenal lahir;

(6) Surat keterangan berbadan sehat dari puskesmas atau petugas kesehatan yang berwenang; dan

(7) Surat permohonan menjadi perangkat Desa yang dibuat oleh yang bersangkutan di atas kertas segel atau bermaterai cukup bagi perangkat Desa yang diproses melalui penjaringan dan penyaringan.

Melihat ketentuan di atas, calon perangkat desa harus berdomisili di wilayah pemerintahan Desa tersebut dengan menunjukan Kartu Tanda Penduduk ataupun surat keterangan yang menunjukan identitas kependudukannya. Bakal calon perangkat desa penting untuk menganut agama berdasarkan kepercayaannya sebabai amanat Pancasila sila pertama, yang menjadi ideologi negara Indonesia. Selain itu, para bakal calon perangkat desa harus memiliki keteguhan hati dan melaksanakan Pancasila, taat terhadap UUD 1945, serta bertoleransi terhadap kebhinekaan yang menjadi jati diri negara Indonesia. Menunjukan akta kelahiran, surat keterangan sehat dari dokter, serta membuat permohonan untuk menjadi calon perangkat desa, dan akan mengikuti proses penjaringan sesuai dengan ketentuan yang berlaku.

\section{b. Mekanisme Pengangkatan Perangkat Desa}


Mekanismepengangkatan perangkat Desa, diatur dengan Pasal 66 PP Desa, yaitu: ${ }^{29}$

(1) Kepala Desa melakukan penjaringan dan penyaringan atau seleksi calon perangkat Desa;

(2) Kepala Desa melakukan konsultasi dengan camat atau sebutan lain mengenai pengangkatan perangkat Desa;

(3) Camat atau sebutan lain memberikan rekomendasi tertulis yang memuat mengenai calon perangkat Desa yang telah dikonsultasikan dengan kepala Desa; dan

(4) Rekomendasi tertulis camat atau sebutan lain dijadikan dasar oleh kepalaDesa dalam pengangkatan perangkat Desa dengan keputusan kepala Desa.

Berdasarkan ketentuan di atas, maka Kepala Desa maupun Penjabat Kepala Desa sebagai pimpinan pemerintahan desa yang berwenang untuk melakukan rekrutmen perangkat desa, menjadi aktor utama terselenggaranya kegiatan tersebut. Adapun langkah yang dilakukan yaitu konsultasi untuk pengangkatan perangkat desa yang telah dilakukan penjaringan, dari hasil konsultasi tersebut Kepala Desa meminta rekomendasi secara tertulis mengenai rencana pengangkatan, serta penetapan pengangkatan perangkat desa tersebut dengan keputusan Kepala Desa, sebagai finalisasi mekanisme perekrutan perangkat desa dalam sebuah sistem pemerintahan Desa berdasarkan peraturan perundang-undangan yang berlaku.

\section{c. Mekanisme Pengangkatan perangkat Desa berdasarkan Permendagri Desa}

Selanjutnya,Pasal 4 Ayat (1) Permendagri Desa juga mengatur pengangkatan Perangkat Desa, yaitu: ${ }^{30}$

${ }^{29}$ Lihat Pasal 66 Peraturan Pemerintah Nomor 47 Tahun 2015 Tentang Desa

${ }^{30}$ Lihat Pasal 4 Ayat (1) Peraturan Menteri Dalam Negeri Nomor 66 Tahun 2017 Tentang

Pengangkatan dan Pemberhentian Kepala Desa. 
(1) Kepala Desa dapat membentuk Tim yang terdiri dari seorang ketua, seorang sekretaris dan minimal seorang anggota;

(2) Kepala Desa melakukan penjaringan dan penyaringan calon Perangkat Desa yang dilakukan oleh Tim;

(3) Pelaksanaan penjaringan dan penyaringan bakal calon Perangkat Desa dilaksanakan paling lama 2 (dua) bulan setelah jabatan perangkat desa kosong atau diberhentikan;

(4) Hasil penjaringan dan penyaringan bakal calon Perangkat Desa sekurang-kurangnya 2 (dua) orang calon dikonsultasikan oleh Kepala Desa kepada Camat;

(5) Camat memberikan rekomendasi tertulis terhadap calon Perangkat Desa selambat-lambatnya 7 (tujuh) hari kerja;

(6) Rekomendasi yang diberikan Camat berupa persetujuan atau penolakan berdasarkan persyaratan yang ditentukan;

(7) Dalam hal Camat memberikan persetujuan, Kepala Desa menerbitkan Keputusan Kepala Desa tentang Pengangkatan Perangkat Desa; dan

(8) Dalam hal rekomendasi Camat berisi penolakan, Kepala Desa melakukan penjaringan dan penyaringan kembali calon Perangkat Desa.

Pada Permendagi di atas, sebenarnya mekanisme pengangkatan perangkat Desa ini sama dengan PP Desa. Hanya, pada Permendagi ini terdapat penambahan beberapa poin untuk mekanisme perekrutan, yaitu pembentukan tim seleksi, yaitu seorang ketua dan seorang sekretaris dengan tujuan perekrutan bakal calon perangkat desa dapat lebih fokus serta dapat dipertanggungjawabkan hasilnya. Selanjutnya, pemberian tugas kepada tim untuk melakukan rekrutment, penjelasan mengenai vulume peserta yang lolos penjaringan, untuk tahap konsultasi oleh Kepala Desa kepada Camat dengan jumlah sekutang-kurangnya 2 orang yang terjaring oleh tim seleksi. Pengaturan waktu pemberian rekomendasi Camat, dengan tenggang waktu paling lambat 7 hari setelah permohonan rekomendasi dari Kepala Desa, 
adapun isi dari rekomendasi tersbut adalah persetujuan dan penolakan. Untuk calon perangkat desa berdasarkan rekomendasi oleh kepala desa kepada camat tersebut diterima, maka Kepala Desa menerbitkan surat keputusan tentang pengangkatan perangkat Desa, sehingga perangkat desa tersebut resmi menjadi aparatur pemerintahan Desa. Adapun rekomendasi yang diajukan oleh Kepala Desa kepada Camat tersebut tidak diterima, maka calon perangkat desa dinyatakan gugur, selanjutnya dilaksanakan kembali penyaringan perangkat Desa.

Berdasarkan analisis yang telah ditempuh dalam memperoleh jawaban dari penelitian ini, maka dapat disimpulkan bahwa Penjabat Kepala Desa berwenang untuk mengangkat perangkat desa berdasarkan peraturan perundang-undangan yang berlaku. selain itu mekanisme pengangkatan dilaksanakan dengan dibentuk tim oleh Kepala Desa, dengan ketentuan satu orang ketua dan satu orang sekretaris. Selanjutnya proses yang telah dilakukan dikonsultasikan untuk mendapatkan rekomendasi camat oleh Kepala Desa. Adapun calon perangkat desa yang disetujui berdasarkan rekomendasi Camat maka Kepala Desa Mengeluarkan Surat Keputusan Tentang Pengangkatan Perangkat Desa. Adapun rekomendasi tersebut ditolak maka dilakukan proses seleksi perangkat desa kembali

\section{PENUTUP}

Penjabat Kepala Desa dapat mengangkat perangkat desa berdasarkan Pasal 4A Ayat (2) Permendagri desa, yaitu melaksanakan tugas dan wewenang Kepala Desa sampai dengan dilantiknya Kepala Desa hasil pemilihan langsung secara serentak sesuai dengan ketentuan peraturan perundang-undangan.

Berdasarkan kewenangan yang melekat pada Penjabat Kepala Desa yang melaksanakan tugas dan wewenang Kepala Desa, maka dapat disimpulkan mekanismenya pengankatan perangkat Desa tidak ada perbedaan antara pengangkatan oleh Penjabat Kepala Desa maupun oleh Kepala Desa. Adapun mekanisme pengangkatan perangkat desa berdasarkan persyaratan umum dan khusus, serta persyaratan administratif. 
Proses perekrutan Perangkat Desa oleh Penjabat Kepala Desameliputi pembentukan tim, penjaringan dan penyaringan bakal calon perangkat Desa oleh tim paling lambat dua bulan setelah perangkat Desa berhenti (calon perangkat Desa yang terjaring dan tersaring paling sedikit dua orang), konsultasi dan mendapatkan rekomendasi dari camat selambat-lambatnya tujuh hari,Penjabat Kepala Desa membuat keputusan pengangkatan apabila mendapat persetujuan Camat, dan melakukan penjaringan kembali apabila usulan tersebut ditolak oleh Camat. 


\section{DAFTAR PUSTAKA}

\section{Buku}

Abdulkadir Muhammad, Etika Profesi Hukum, PT. Citra Aditya Sakti, Bandung, 2006.

Marihot Tua Efendi Hariandia, Manajemen Sumber Daya Manusia Pengadaan, Pengembangan, Pengkompensasian, dan Peningkatan Produktifitas Pegawai, Grasindo, Jakarta, 2002.

Moh. Kusnadi dan Harmaili Ibrahim, Pengantar Hukum Tata Negara,PD. Budi Chaniago, Jakarta Selatan, 1988.

Pipin Syaripin, Pengantar Ilmu Hukum, CV. Pustaka Setia, Bandung, 1999.

Pipin Syarifin dan Dedah Jubaedah, Hukum Pemerintahan Daerah, Pustaka Bani Quraisy, Bandung, 2005.

Sutjipto Rahardjo, Ilmu Hukum Cetakan Ke 6, PT. Citra Aditya Bakti, Semarang, 2006.

S. Soekano dan S. Mamuji, Penelitian Hukum Normatif Suatu TinjauanSingkat. cetakan ke-2, PT. Raja Graf. Persada, Jakarta, 2009.

Uniarso Ridwan dan Achmad Sodik Sudrajat, Hukum Administrasi Negara dan Kebijakan Pelayanan Publik, Nuansa, Bandung, 2012.

\section{Peraturan Perundang-Undangan}

Undang-Undang Dasar Tahun 1945

Undang-Undang Nomor 6 Tahun 2014 Tentang Desa

Peraturan Pemerintah Nomor 47 Tahun 2015 Tentang Desa

Peraturan Menteri Dalam Negeri Nomor 66 Tahun 2017 Tentang Pengangkatan dan Pemberhentian Kepala Desa.

Peraturan Menteri Dalam Negeri Nomor 83 Tahun 2015 Tentang Pengangkatan dan Pemberhentian Perangkat Desa

\section{Jurnal}

Arief Sumeru, "Kedudukan Kepala Desa Dalam Penyelenggaraan Pemerintahan Desa", JKMP, Vol. 4, No. 1, Maret 2016.

Agus Adhari, "Analisis Hukum Pembentukan Badan Usaha Milik Desa Dalam Upaya Meningkatkan Pendapatan Asli Desa di Kecamatan Babalan Kabupaten Langkat", Dialogia Lulidca: Jurnal Hukum Bisnis dan Inverstasi, Vol. 9 No. 1, November 2017.

Baharudin Muhammad Faturahman, "Aktualisasi Demokrasi dalam Perekrutan dan Penjarungan Perangkat Desa, Jurnal Sospol Vol. 4 No. 1, Januari-Juni 2018. Efik Yusdiansyah, "Peran Badan Legislasi Daerah Dalam Mmenjalankan Fungsi Legislasi di DPRD Provinsi Jawa Barat", SYIAR HUKUM, VoL. XIV No. 2, September 2012 - Januari 2013, Hal. 189. 
Muhammad Siwi Nugraha, "Tantangan Mewujudkan Meritokrasi Birokrasi Pemerintahan Desa", Gema Publica Jurnal Manajemen dan Kebijakan Publik, Vol. 4 No. 2, Oktober 2019.

Nuraini dan Irwan Nasution, "Kinerja Aparat Desa Dalam Penyelenggaraan Pemerintahan Desa Pantai Labu Pekan", Jurnal Ilmu Pemerinahan dan Sosial Politik 2 (2) (2014)

Nanang Zulkarnaen, "Kewenangan Kepala Desa Dalam Mengangkat dan Memberhentikan Perangkat Desa Ditinjau Dari Undang-Undang Nomor 6 Tahun Tentang Desa",Civicus PKIP UMMat, Vol. 6 No. 1 Maret, 2018.

Ren Yani, Dkk., "Degradasi Integritas Publik Politisi Dalam Penggunaan Anggaran Dana Desa Bukit Pamewa Kecamatan Sipora Utara Kabupaten Kepulauan Mentawai”, JISPO, Vol. 8 No. 2, Juli-Desember 2018.

Simson Tondo, "Perebutan Desa: Tinjauan Pemilihan Kepala Desa Serentak di Kabupaten Halmehera Utara Tahun 2018", Gema Publica Jurnal Manajemen dan Kebijakan Publik, Vol. 4 No. 1, Maret 2019.

Vela Graeta Widyasari,'Diskresi Kepala Daerah Dalam Penetapan Penjabat Kepala Desa", Lentera Hukum, Vol. 3 No. 2, Juli 2016. 